\title{
PENGARUH DEBT TO EQUITY RATIO, PROFITABILITAS, KUALITAS AUDITOR DAN PERGANTIAN AUDITOR TERHADAP KETEPATAN WAKTU PELAPORAN KEUANGAN PADA PERUSAHAAN MANUFAKTUR YANG TERDAFTARDI BEI
}

\author{
Gita Desyana, SE., MM., Ak., CA \\ Fakultas Ekonomi dan Bisnis Universitas Tanjungpura
}

\begin{abstract}
This study aims to find empirical evidence whether factors such as debt to equity ratio, profitability, auditor quality, and auditor turnover affect the compliance of manufacturing companies in the timely submission of financial statements on the Indonesia Stock Exchange.

The data in this study are secondary data obtained from the company's annual financial statements in the Indonesian Stock Exchange (IDX). This type of research is ex post facto research. This research was conducted using a sample of 76 manufacturing companies listed on the Indonesia Stock Exchange for the period of 2016-2018, so the research data analyzed amounted to 201. The data analysis technique used was descriptive statistics, multivariate test using logistic regression. Based on hypothesis testing, it can be concluded that overall, the companies that are on time are more numerous than the companies that are not on time in financial reporting to Bapepam. And the test results with logistic regression show empirical evidence that debt to equity ratio, profitability, auditor quality, and auditor turnover do not affect the timeliness of corporate financial reporting.
\end{abstract}

Keywords : Debt To Equity Ratio, Profitability, Auditor Quality, Auditor Change And Timeliness. 


\section{PENDAHULUAN}

Pelaporan keuangan merupakan sarana bagi perusahaan untuk menyampaikan berbagai informasi dan pengukuran secara ekonomi mengenai sumber daya yang dimiliki serta kinerjanya kepada berbagai pihak yang memiliki kepentingan atas informasi tersebut. Salah satu informasi yang penting bagi pemakai yang berkaitan dengan laporan keuangan adalah informasi Leverage keuangan dan profitabililitas perusahaan. Para pemakai sering menjadikan leverage keuangan yang diukur dengan debt to equity ratio dan Profitabilitas perusahaan yang berasal dari laporan keuangan sebagai salah satu indikator untuk landasan di dalam pengambilan keputusan berinvestasi. Weston dan Copeland (1995) dalam Hilmi dan Ali (2004) menyatakan bahwa rasio leverage mengukur tingkat aktiva perusahaan yang telah dibiayai oleh penggunaan hutang. Sedangkan rasio rentabilitas atau rasio Profitabilitas digunakan untuk menunjukkan keberhasilan perusahaan di dalam menghasilkan keuntungan (Ang, 1997).

Badan Pengawas Pasar Modal dalam peraturannya mewajibkan bahwa laporan keuangan tahunan yang dilaporkan perusahaan yang go public harus terlebih dahulu diaudit oleh akuntan yang terdaftar di Badan Pengawas Pasar Modal dan Lembaga Keuangan. Keharusan laporan keuangan diaudit mendorong Kantor Akuntan Publik untuk meningkatkan kualitas atas hasil auditnya.

Ketepatwaktuan (timeliness) merupakan salah satu faktor penting dalam penyajian laporan keuangan kepada publik sehingga perusahaan diharapkan untuk tidak menunda penyajian laporan keuangannya agar informasi tersebut tidak kehilangan kemampuannya dalam mempengaruhi pengambilan keputusan.

Menurut hasil penelitian Respati (2001) dan Na'im (1998) mengenai Profitabilitas yang mempunyai pengaruh terhadap ketepatan pelaporan keuangan bertentangan dengan hasil penelitian Megawati (2005) yang menyatakan bahwa Profitabilitas tidak berpengaruh terhadap ketepatan pelaporan keuangan. Sedangkan hasil penelitian Hilmi dan Ali (2008) mengenai kualitas auditor yang berpengaruh pada ketepatan waktu pelaporan keuangan bertentangan dengan hasil penelitian dari Anissa (2004).

Dari uraian diatas dapat disimpulkan bahwa terdapat perbedaan hasil penelitian pada beberapa peneliti untuk variabel penelitian yang sama, mendorong untuk melakukan pengujian kembali mengenai faktor-faktor seperti debt to equity ratio, 
Profitabilitas, dan kualitas auditor yang mempengaruhi ketepatan waktu pelaporan keuangan perusahaan di Indonesia, khususnya perusahaan manufaktur. Pemilihan perusahaan-perusahaan publik yang masuk kategori perusahaan manufaktur ini didasarkan pada pertimbangan akan homogenitas dalam aktivitas produksinya dan kelompok industri ini yang relatif lebih besar jika dibandingkan dengan kelompok industri yang lain di Bursa Efek Indonesia.

Adapun yang membedakan penelitian ini dengan penelitian sebelumnya yakni dalam penelitian ini dimasukkan variabel pergantian auditor dalam mengaudit laporan keuangan tahunan perusahaan selama 3 periode berturut-turut yaitu periode 2016, 2017, 2018

\section{KAJIAN LITERATUR}

\section{Laporan Keuangan}

Laporan keuangan bagi suatu perusahaan merupakan alat penguji untuk menentukan atau menilai posisi keuangan perusahaan. Dalam Standar Akuntansi Keuangan (IAI, 2007) disebutkan bahwa laporan keuangan merupakan bagian dari pelaporan keuangan. Laporan keuangan yang lengkap biasanya meliputi neraca, laporan laba rugi, laporan perubahan posisi keuangan (yang dapat disajikan dalam berbagai cara, misalnya sebagai laporan arus kas atau laporan arus dana), catatan dan laporan lain serta materi penjelasan yang merupakan bagian integral dari laporan keuangan. Disamping itu juga termasuk skedul-skedul dan informasi tambahan yang berkaitan dengan laporan tersebut, misalnya informasi keuangan segmen industri dan geografis, serta pengungkapan pengaruh perubahan harga.

\section{Ketepatan Waktu (Timeliness)}

Menurut IAI (2007) bahwa tujuan laporan keuangan adalah menyediakan informasi yang menyangkut posisi keuangan, kinerja, serta perubahan posisi keuangan suatu perusahaan yang bermanfaat bagi sejumlah besar pengguna dalam pengambilan keputusan ekonomi. Informasi yang relevan akan bermanfaat bagi para pemakai apabila tersedia tepat waktu sebelum pemakai kehilangan kesempatan atau kemampuan untuk mempengaruhi keputusan yang akan diambil. Tepat waktu diartikan bahwa informasi 
harus disampaikan sedini mungkin untuk dapat digunakan sebagai dasar untuk membantu dalam pengambilan keputusan- keputusan ekonomi dan untuk menghindari tertundanya pengambilan keputusan tersebut (Baridwan, 1997).

\section{Debt to Equity Ratio}

Rasio debt to equity dikenal juga sebagai rasio financial leverage. Menurut Weston dan Copeland (1995) dalam Hilmi dan Ali (2008) menyatakan bahwa rasio leverage mengukur tingkat aktiva perusahaan yang telah dibiayai oleh penggunaan hutang. Tingginya rasio debt to equity mencerminkan tingginya resiko perusahaan.

\section{Profitabilitas}

Menurut Ang (1997), rasio rentabilitas dan Profitabilitas menunjukkan keberhasilan perusahaan di dalam menghasilkan keuntungan. Return on Asset (ROA) biasanya disebut sebagai hasil pengembalian atas total aktiva. Rasio ini mencoba mengukur efektivitas pemakaian total sumber daya oleh perusahaan. Kadang-kadang rasio ini disebut hasil pengembalian atas investasi (ROI) (Weston dan Copeland, 1995).

\section{Kualitas Auditor}

Laporan keuangan yang disampaikan kepada Bapepam merupakan laporan keuangan yang telah diaudit oleh akuntan publik. Auditor yang berkualitas tinggi harus memenuhi Standar Profesional Akuntan Publik (SPAP). Standar umum pertama menyebutkan bahwa audit harus dilaksanakan oleh seorang atau lebih yang memiliki keahlian dan pelatihan teknis yang cukup sebagai auditor.

\section{Pergantian Auditor}

Pergantian akuntan publik dilakukan karena telah berakhirnya kontrak kerja yang disepakati antara Kantor Akuntan Publik dengan pemberi tugas dan telah memutuskan untuk tidak memperpanjang dengan penugasan baru. Penugasan auditor terjadi karena beberapa alasan antara lain perusahaan klien merupakan merger antara beberapa perusahaan yang semula memiliki auditor masng-masing yang berbeda kebutuhan akan 
adanya jasa profesional yang lebih luas atau tidak puas terhadap Kantor Akuntan Publik lama.

\section{Hubungan Debt To Equity Dengan Ketepatan Waktu Pelaporan Keuangan}

Rasio debt to equity juga dikenal sebagai rasio financial leverage. Tingg inya debt to equity ratio mencerminkan tingginya risiko keuangan perusahaan Tingginya resiko ini menunjukkan adanya kemungkinan bahwa perusahaan tersebut tidak bisa melunasi kewajiban atau hutangnya baik berupa pokok maupun bunganya. Resiko perusahaan yang tinggi mengindikasikan bahwa perusahaan mengalami kesulitan keuangan. Sedangkan kesulitan keuangan dianggap berita buruk yang akan mempengaruhi kondisi perusahaan dimata publik. Sehingga pihak manajemen cenderung akan menunda penyampaian laporan keuangan yang memuat berita buruk. Berkaitan dengan teori agensi, maka agen harus bisa mengelola hutang yang dimiliki oleh perusahaan. Apabila perusahaan memiliki sedikit hutang maka masih bisa dikatakan wajar karena hutang tersebut dapat memperbesar arus kas masuk dan dapat digunakan untuk menghasilkan laba perusahaan lebih banyak. Tetapi bila hutang perusahaan terlalu besar (Debt to Equity terlalu besar) maka perusahaan tidak akan dapat membayar pinjaman dan bunga pinjaman. Ketidakmampuan perusahaan membayar hutang mencerminkan bahwa agen tidak dapat bekerja sesuai kepentingan principal yang nantinya dapat berpengaruh pada kepentingan principal maupun agen, sehingga agen berusaha untuk menunda penyampaian informasi. Oleh karena itu, semakin tinggi rasio debt to equity suatu perusahaan maka perusahaan tersebut akan semakin tidak tepat waktu dalam penyampaian laporan keuangan perusahaan (menunda informasi). Berdasarkan uraian diatas, maka hipotesis yang dapat disusun adalah sebagai berikut :

$\mathrm{H} 1$ : debt to equity ratio berpengaruhi negatif terhadap ketepatan waktu pelaporan keuangan.

\section{Hubungan Profitabilitas Dengan Ketepatan Waktu Pelaporan Keuangan}

Profitabilitas menunjukkan keberhasilan perusahaan didalam menghasilkan keuntungan. Dengan semakin besar rasio Profitabilitas maka semakin baik pula kinerja perusahaan sehingga perusahaan akan cenderung untuk memberikan informasi 
tersebut pada pihak lain yang berkepentingan. Sehingga dapat dikatakan bahwa profit merupakan berita baik (good news) bagi perusahaan. Perusahaan yang memiliki berita baik tidak akan menunda penyampaian informasi. Berkaitan dengan teori agensi, manajemen tidak akan menunda penyampaian informasi mengenai profit perusahaan kepada prinsipal karena berhubungan dengan kompensasi keuangan yang akan diterima oleh agen dan karena merupakan berita baik bagi prinsipal maka kemungkinan besar prinsipal akan menggunakan agen yang sama untuk mengelola perusahaan. Perusahaan yang mampu menghasilkan profit cenderung lebih tepat waktu dalam pelaporan keuangannya dibandingkan perusahaan yang mengalami kerugian (Oktarina dan Suharli, 2005). Hal ini didukung oleh penelitian Na'im (1999) yang menemukan bukti empiris bahwa Profitabilitas signifikan mempengaruhi ketepatan waktu pelaporan keuangan. Berdasarkan uraian diatas, maka hipotesis yang dapat disusun adalah sebagai berikut:

H2 : Profitabilitas berpengaruhi positif terhadap ketepatan waktu pelaporan keuangan

\section{Hubungan Kualitas Auditor (Kap) Dengan Ketepatan Waktu Pelaporan Keuangan}

De Angelo (1981) dalam Anissa (2004) mendefinisikan kualitas audit sebagai gabungan probabilitas pendeteksian dan pelaporan kesalahan laporan keuangan yang material. Beliau menyimpulkan bahwa Kantor Akuntan Publik yang lebih besar, kualitas audit yang dihasilkan juga lebih baik. Kualitas auditor yang mengaudit perusahaan sangat penting, auditor yang berkualitas merupakan informasi baik sehingga manajemen akan segera menyampaikan laporan keuangan yang diaudit oleh kantor akuntan publik yang memiliki reputasi baik. Perusahaan yang diaudit oleh KAP yang berkualitas baik akan melaporkan laporan keuangan perusahaan lebih tepat waktu dibandingkan perusahaan yang diaudit oleh KAP yang kurang berkualitas. Hubungannya dengan teori agensi, manajer sebagai agen yang telah diberikan wewenang untuk mengelola perusahaan oleh prinsipal akan cenderung memilih Kantor Akuntan Publik yang berkualitas untuk menilai laporan keuangan perusahaan karena dinilai lebih efektif dalam mengaudit dan menghasilkan laporan audit yang sesuai dengan kewajaran laporan keuangan perusahaan. Dalam literatur tersebut kualitas auditor diukur dengan ukuran apakah Kantor Akuntan Publik yang memberikan jasa audit merupakan anggota dari The Big Four atau bukan. Seperti hasil penelitian Oktarina dan Suharli (2005) yang 
menyatakan bahwa penggunaan kantor akuntan besar mempengaruhi ketepatan waktu pelaporan keuangan. Hal ini disebabkan KAP besar mampu mengerjakan pekerjaan auditnya secara lebih efisien dan efektif sehingga dapat selesai secara tepat waktu. Berdasarkan uraian diatas, maka hipotesis yang dapat disusun adalah sebagai berikut :

H3 : Kualitas Auditor (KAP) berpengaruh positif terhadap ketepatan waktu pelaporan keuangan

\section{Hubungan Pergantian Auditor Dengan Ketepatan Waktu Pelaporan Keuangan.}

Pernyataan Standar Auditing (PSA) No.16 mensyaratkan adanya komunikasi baik lisan maupun tulisan antara auditor pendahulu dengan auditor pengganti sebelum menerima penugasan. Berbeda dengan penugasan pertama sebagai akibat adanya pergantian auditor, pada penugasan ulang auditor memiliki akses pada semua program yang digunakan pada periode yang lalu dan kertas kerja yang berkaitan dengan program tersebut. Banyaknya prosedur yang ditempuh auditor pengganti dalam proses pengauditan memerlukan waktu yang lebih lama dibandingkan jika auditor tersebut melanjutkan penerimaan penugasan. Hal ini bisa mengakibatkan lamanya pengauditan yang berakibat juga pada penundaan penyampaian laporan keuangan auditan (Ksa, 2003). Berdasarkan uraian diatas, maka hipotesis yang dapat disusun adalah sebagai berikut :

H4 : Pergantian auditor berpengaruhi negatif terhadap ketepatan waktu pelaporan keuangan perusahaan.

\section{METODE PENELITIAN}

Jenis penelitian yang digunakan yaitu deskriptif kuantitatif. Penelitian ini dikatagorikan sebagai penelitian ex post facto yaitu tipe penelitian terhadap data yang dikumpulkan setelah terjadinya suatu fakta atau peristiwa. Populasi penelitian sejumlah 150 perusahaan manufaktur yang terdaftar di Bursa Efek Idonesia periode 2016-2018 yang seluruh data keuangannya telah diterbitkan dan telah diaudit oleh akuntan publik. Jumlah perusahaan sampel yang digunakan dalam penelitian ini sebanyak 125 perusahaan per tahun pada periode tahun 2016, 2017, 2018, sehingga didapatkan jumlah sampel (n) sebanyak $125 \times 3$ periode $=375$ sampel. Variabel dalam penelitian ini terdiri dari: 
a. Variabel Dependen

Variabel dependen dalam penelitian ini adalah ketepatan waktu, dimana kategori 0 untuk perusahaan yang tidak tepat waktu dan kategori 1 untuk perusahaan yang tepat waktu. Ketepatan waktu menunjukkan rentang waktu antara penyajian informasi yang diinginkan dengan frekuensi pelaporan informasi. Ketepatan waktu diukur dengan dummy varibel, dimana kategori 1 untuk perusahaan yang tepat waktu dan kategori 0 untuk perusahaan yang tidak tepat waktu. Perusahaan di kategorikan terlambat jika laporan keuangan dilaporkan setelah tanggal 31 Maret, sedangkan perusahaan yang tepat waktu adalah perusahaan yang menyampaikan laporan keuangan sebelum tanggal 1 April.

b. Variabel Independen

Variabel independen dalam penelitian ini adalah debt to equity ratio, Profitabilitas, kualitas auditor, dan pergantian auditor.

\section{Debt to Equity Ratio (DER)}

Debt to Equity Ratio (DER) digunakan untuk mengukur tingkat leverage (penggunaan utang) terhadap total shareholder's equity yang dimiliki perusahaan. Debt to Equity Ratio (DER) juga dapat memberikan gambaran mengenai struktur modal yang dimiliki oleh perusahaan, sehingga dapat dilihat tingkat risiko tak tertagihnya suatu utang (Ang, 1997).

\section{Profitabilitas (ROA)}

Profitabilitas diukur dengan menggunakan return on asset (ROA) dan return on equity (ROE). Indikator yang digunakan untuk mengukur tingkat Profitabilitas dalam penelitian ini adalah return on asset (ROA) seperti yang digunakan oleh beberapa peneliti yang memiliki hasil berbeda di dalam penelitiannya seperti Ainun Na'im, Novita Weningtyas Respati, Rachmaf Saleh, dan Megawati. Return on Asset (ROA) merupakan rasio untuk mengukur efektivitas perusahaan didalam menghasilkan keuntungan dengan cara memanfaatkan aktiva yang dimilikinya. Besarnya ROA diketahui dengan membandingkan laba bersih setelah pajak dan rata-rata total aktiva (Ang, 1997). 


\section{Kualitas Auditor (KAP)}

Reputasi auditor sering digunakan sebagai gambaran dari kualitas audit, reputasi auditor didasarkan pada kepercayaan pemakai jasa auditor. Auditor skala besar juga lebih cenderung untuk mengungkapkan masalah-masalah yang ada karena mereka lebih kuat menghadapi risiko proses pengadilan. Argumen tersebut berarti bahwa auditor skala besar memiliki insentif lebih untuk mendeteksi dan melaporkan masalah yang terdapat pada perusahaan yang diauditnya. Natawidnyana (2008) menyebutkan klasifikasi auditor yang termasuk dalam The Big Four sejak tahun 2002 adalah : Ernst \& Young, Deloitte Touche Tohmatsu, KPMG Peat Marwick, Price Waterhouse Coopers.

Variabel ini diukur dengan menggunakan model regresi dichotomus atau merupakan variabel dummy, dimana kategori 1 untuk perusahaan yang merupakan klien KAP the big four dan angka 0 untuk perusahaan yang bukan klien KAP the big four.

\section{Pergantian Auditor}

Pergantian akuntan publik terjadi jika kontrak kerja yang disepakati antara kantor akuntan publik dengan pemberi tugas telah berakhir dan memutuskan untuk tidak memperpanjang dengan penugasan baru. Dalam penelitian ini pergantian auditor merupakan variabel dummy, dimana apabila perusahaan yang tidak melakukan pergantian auditor termasuk kategori 1, sedangkan apabila perusahaan melakukan pergantian auditor maka termasuk kategori 0 .

Metode analisis yang dilakukan secara kuantitatif sebagai berikut :

a. Statistik deskriptif

Statistik deskriptif digunakan untuk mendiskripsikan variabel-variabel dalam penelitian ini. Alat analisis yang digunakan adalah rata-rata (mean) dan standar deviasi.

b. Uji Hipotesis

Pengujian hipotesis dilakukan secara uji multivariate dengan menggunakan regresi logistik. Regresi logistik digunakan untuk menguji apakah variabelvariabel debt to equity ratio, Profitabilitas, kualitas auditor, dan pergantian auditor mempengaruhi ketepatan waktu pelaporan keuangan. 
Analisis pengujian dengan regresi logistik menurut Ghozali (2001) memperhatikan hal-hal sebagai berikut :

a. Menilai Kelayakan Model Regresi

Analisis pertama yang dilakukan adalah menilai kelayakan model regresi logistik yang akan digunakan. Pengujian kelayakan model regresi logistik dilakukan dengan menggunakan Goodness of fit test yang diukur dengan nilai Chi-Square pada bagian bawah uji Homser and Lemeshow.

Perhatikan output dari Hosmer and Lemeshow dengan hipotesis :

H0 : Model yang dihipotesakan fit dengan data

HA : Model yang dihipotesakan tidak fit dengan data Dasar pengambilan keputusan :

Perhatikan nilai goodness of fit test yang diukur dengan nilai chi square pada bagian bawah uji Hosmer and Lemeshow :

Jika probabilitas > 0,05 maka $\mathrm{H} 0$ diterima

Jika probabilitas $<0,05$ maka H0 ditolak

b. Penilaian Keseluruhan Model (overall model fit)

Langkah selanjutnya adalah menguji keseluruhan model regresi (overall model fit). Pengujian dilakukan dengan membandingkan nilai antara -2 Log Likelihood (-2LL) pada awal (Block Number $=0$ ) dengan nilai -2 Log Likelihood (-2LL) pada akhir (Block Number $=1$ ). Adanya pengurangan nilai antara $-2 \mathrm{LL}$ awal dengan nilai $-2 \mathrm{LL}$ pada langkah berikutnya menunjukkan bahwa model yang dihipotesakan fit dengan data (Ghozali, 2001).

c. Menguji koefisien Regresi

Dalam pengujian koefisien regresi perlu memperhatikan beberapa hal berikut : Tingkat signifikasi $(\alpha)$ yang digunakan sebesar 5 persen. Mason (1999) dalam Respati (2001) menyatakan bahwa tidak terdapat satu level signifikansi yang dapat diaplikasikan untuk semua pengujian.

Kriteria penerimaan dan penolakan hipotesis didasarkan pada signifikansi $p$-value (probabilitas value). Jika $p$-value $>\alpha$, maka hipotesis alternatif ditolak, sebaliknya jika $p$-value $>\alpha$ maka hipotesis alternatif diterima. 


\section{HASIL DAN PEMBAHASAN}

Pengujian hipotesis menggunakan model regresi logistik untuk menguji penga ruh Debt to Equity Ratio (DER), profitabilitas yang diproksi dengan ROA, struktur kepemilikan pihak luar, kualitas auditor (KAP) dan pergantian auditor (AUDCH) terhadap ketepatan waktu pelaporan keuangan perusahaan. Pengujian hipotesis meliputi (1) menilai kelayakan model regresi, (2) menilai keseluruhan model, dan (3) menguji koefisien regresi.

\section{Menilai kelayakan model regresi (goodness of fittest)}

Langkah pertama yang dilakukan adalah menilai kelayakan model regresi. Perhatikan nilai goodness of fit test pada tabel 4.1 yang diukur dengan nilai chi-square pada bagian bawah uji Hosmer and Lemeshow. Pada tabel tersebut terlihat bahwa besarnya nilai statistik Hosmer and Lemeshow Goodness of fit test sebesar 2,728 dengan probabilitas signifikansi 0,950 yang nilainya di atas 0,05 .

Tabel 4.1

Hosmer and lemeshow test

\begin{tabular}{|l|l|l|l|}
\hline Step & Chi-square & df & Sig. \\
\hline 1 & 2,728 & 8 &, 950 \\
\hline
\end{tabular}

Sumber : data diolah tahun 2019

Karena angka probabilitas > 0,05 maka $\mathrm{H} 0$ diterima. Hal ini berarti model regresi layak dipakai untuk analisa selanjutnya, karena tidak ada perbedaan yang nyata antara klasifikasi yang diprediksi dengan klasifikasi yang diamati.

\section{Menilai keseluruhan model (overall model fittest)}

Langkah kedua adalah menilai keseluruhan model regresi. Tabel 4.2 menunjukkan uji kelayakan dengan memperhatikan angka pada -2 Log Likelihood (-2 LL) Block Number $=0$ dan -2 LL Block Number $=1$. Pada tabel tersebut terlihat bahwa angka awal -2 LL Block Number $=0$ adalah 46,813 sedangkan angka -2 LL Block Number $=1$ adalah 39,562. 
Tabel 4.2

Overall Model Fit Test

\begin{tabular}{|l|l|}
\hline $\begin{array}{l}\text { Block Number }=0 \\
-2 \text { Log Likelihood }\end{array}$ & $\begin{array}{l}\text { Block Number }=1 \\
-2 \text { Log Likelihood }\end{array}$ \\
\hline 46,813 & 39,562 \\
\hline
\end{tabular}

Sumber : data diolah tahun 2019

Dari model tersebut ternyata overall model fit pada -2 LL Block Number $=0$ menunjukkan adanya penurunan pada -2 LL Block Number $=1$. Penurunan likelihood ini menunjukkan model regresi yang lebih baik atau dengan kata lain model yang dihipotesiskan fit dengan data.

\section{Menguji koefisien regresi}

Tahap akhir adalah uji koefisien regresi, di mana hasilnya dapat dilihat pada table 4.3. Tabel tersebut menunjukkan hasil pengujian dengan regresi logistik pada tingkat signifikansi 5 persen. Hasil output SPSS regresi logistic memberikan nilai Cox dan Snell's R sebesar 0,035 dan nilai Nagelkerke R2 sebesar 0,171. yang berarti variabilitas variabel dependen yang dapat dijelaskan oleh variabilitas variabel independen sebesar 3,5 persen. Pengujian persamaan regresi logistik tersebut, maka diperoleh model regresi logistik sebagai berikut:

$$
\mathrm{Ln}=2,481-0,005 \mathrm{DER}-2,533+18,235 \mathrm{KAP}+0,911 \mathrm{AUDCH}
$$

Tabel 4.3

Hasil Uji Koefisien Regresi Logistik

\begin{tabular}{|c|c|c|c|c|c|c|}
\hline & B & S.E. & Wald & df & Sig. & Exp(B) \\
\hline DER &,- 005 &, 049 &, 012 & 1 &, 912 &, 995 \\
\hline ROA & $-2,533$ & 4,568 &, 307 & 1 &, 579 &, 079 \\
\hline KAP & 18,235 & 4160,654 &, 000 & 1 &, 997 & 83059909,460 \\
\hline AUDCH &, 911 &, 953 &, 913 & 1 &, 339 & 2,487 \\
\hline Constant & 2,481 &, 745 & 11,081 & 1 &, 001 & 11,952 \\
\hline
\end{tabular}

*Signifikan pada level 5\%

Sumber : data olahan tahun 2019 
H1 : Debt to Equity Ratio berpengaruh terhadap ketepatan waktu pelaporan keuangan perusahaan.

Variabel hutang perusahaan yang diukur dengan debt to equity ratio (DER) menunjukkan nilai koefisien negatif sebesar -0,005 dengan probabilitas variabel sebesar 0,912 di atas tingkat signifikansi 0,05 (5 persen). Artinya dapat disimpulkan bahwa H1 ditolak. Dengan demikian tidak terbukti bahwa hutang perusahaan berpengaruh terhadap ketepatan waktu pelaporan keuangan perusahaan.

H2: Profitabilitas berpengaruh terhadap ketepatan waktu pelaporan keuangan perusahaan.

Variabel profitabilitas yang diukur dengan Return on Asset (ROA) menunjukkan nilai koefisien negatif sebesar -2,533dengan probabilitas variabel sebesar 0,579 di atas tingkat signifikansi 0,05 (5 persen). Artinya dapat disimpulkan bahwa H2 ditolak. Dengan demikian terbukti bahwa profitabilitas berpengaruh negatif terhadap ketepatan waktu pelaporan keuangan perusahaan.

H3 : Kualitas Auditor berpengaruh terhadap ketepatan waktu pelaporan keuangan perusahaan.

Variabel Kualitas auditor (KAP) menunjukkan nilai koefisien positif sebesar18,235 dengan probabilitas variabel sebesar 0,997 di atas tingkat signifikansi 0,05 (5 persen). Artinya dapat disimpulkan bahwa H3 ditolak. Dengan demikian tidak terbukti bahwa Kualitas Auditor (KAP) berpengaruh terhadap ketepatan waktu pelaporan keuangan perusahaan.

H4 : Pergantian Auditor berpengaruh terhadap ketepatan waktu pelaporan keuangan perusahaan.

Variabel pergantian auditor menunjukkan nilai koefisien negatif sebesar 0,911dengan probabilitas variabel sebesar 0,339 diatas signifikansi 0,05 (5 persen). Hal ini berarti bahwa $\mathrm{H} 4$ ditolak, dengan demikian tidak terbukti bahwa pergantian auditor berpengaruh terhadap ketepatan waktu pelaporan keuangan perusahaan.

\section{Pembahasan}

\section{Debt to Equity Ratio (DER)}

Hasil uji regresi logistik menunjukkan bahwa debt to equity ratio tidak mempengaruhi ketepatan waktu pelaporan keuangan perusahaan. Meskipun temuan ini 
konsisten dengan hasil penelitian yang dilakukan Na'im (1999) dan Respati (2004), tetapi temuan ini tidak konsisten dengan logika teori dalam penelitian. Hal ini mengindikasikan bahwa baik perusahaan yang tepat waktu maupun perusahaan yang tidak tepat waktu dalam pelaporan keuangannya mengabaikan informasi tentang debt to equity ratio. Hal ini sesuai dengan gambaran umum obyek perusahaan bahwa sebagian besar perusahaan yang tepat waktu maupun yang tidak tepat waktu dalam pelaporan keuangan mempunyai hutang lebih dari Rp. 500.000.000.000,00. Hal ini mengindikasikan bahwa perusahaan yang mempunyai hutang banyak ingin mengumumkan laporan keuangan perusahaan khususnya ditujukan pada pihak kreditor dengan tujuan agar kreditor mengetahui kinerja perusahaan dan mengetahui kemampuan perusahaan dalam membayar pinjaman dari kreditor.

\section{Return on Asset (ROA)}

Hasil uji regresi logistik dalam profitabilitas perusahaan yang diukur dengan Return on Asset, menunjukkan bahwa profitabilitas tidak mempengaruhi secara signifikan terhadap ketepatan waktu pelaporan keuangan perusahaan. Hasil ini sesuai dengan penelitian Nurmiati (2016) bahwa hal ini dikarenakan perusahaan tidak mempertimbangkan tingkat profitabilitas yang dimiliki oleh perusahaan tersebut. Perusahaan yang profitabilitasnya tinggi atau rendah sama-sama ingin menyampaikan laporan keuangan tepat waktu tanpa melihat tingkat profitabilitas yang dimiliki perusahaan.

\section{Kualitas Auditor (KAP)}

Hasil uji regresi logistik menunjukkan bahwa kualitas auditor dalam hal ini Kantor Akuntan Publik tidak mempengaruhi ketepatan waktu pelaporan keuangan perusahaan. Hasil penelitian ini sejalan dengan hasil penelitianAnissa (2004), namun tidak sesuai dengan logika teori dalam penelitian ini. Dalam hal manajer sebagai agen yang telah diberikan wewenang untuk mengelola perusahaan oleh prinsipal akan cenderung memilih Kantor Akuntan Publik yang berkualitas untuk menilai laporan keuangan perusahaan karena dinilai lebih efektif dalam mengaudit dan menghasilkan laporan audit yang sesuai dengan kewajaran laporan keuangan perusahaan.. Hal ini dapat dilihat pada 
gambaran umum obyek perusahaan bahwa sebagian besar perusahaan baik yang tepat waktu atau tidak tepat waktu dalam pelaporan keuangan perusahaan diaudit oleh Kantor Akuntan Publik yang termasuk dalam The Big Four. Hal ini menunjukkan bahwa tidak ada jaminan dalam ketepatan waktu pelaporan keuangan perusahaan dengan informasi tentang kualitas auditor.

\section{Pergantian Auditor (AUDCH)}

Hasil uji regresi logistik menunjukkan bahwa pergantian auditor secara signifikan tidak berpengaruh terhadap ketepatan waktu pelaporan keuangan perusahaan. Temuan ini tidak sesuai dengan logika teori dalam penelitian ini bahwa banyaknya prosedur yang ditempuh auditor pengganti dalam proses pengauditan memerlukan waktu yang lebih lama dibandingkan jika auditor tersebut melanjutkan penerimaan penugasan. Temuan ini juga tidak sesuai dengan hasil penelitian yang dilakukan Ksa (2003) yang menyatakan bahwa pergantian auditor mempengaruhi ketepatan waktu pelaporan keuangan

\section{KESIMPULAN}

Dari hasil penelitian data dan pembahasan yang dilakukan, maka diperoleh kesimpulan sebagai berikut: Obyek penelitian terdiri dari 66 perusahaan tepat waktu pada tahun 2016, 65 perusahaan tepat waktu pada tahun 2017 dan 65 perusahaan tepat waktu pada tahun 2018. Sedangkan untuk perusahaan tidak tepat waktu sebanyak 1 perusahaan pada tahun 2016, 2 perusahaan pada tahun 2017 dan 2 perusahaan pada tahun 2018. Dari angka tersebut menunjukkan bahwa secara keseluruhan perusahaan yang tepat waktu lebih banyak dibandingkan dengan perusahaan yang tidak tepat waktu dalam pelaporan keuangan ke Bapepam. Hasil pengujian dengan regresi logistik menunjukkan bukti empiris bahwa debt to equity ratio, profitabilitas, kualitas auditor, dan pergantian auditor tidak berpengaruh terhadap ketepatan waktu pelaporan keuangan perusahaan.

Diharapkan peneliti selanjutnya dapat menambah sampel penelitian dari seluruh perusahaan yang terdaftar pada Bursa Efek Indonesia dan periode pengamatan yang lebih panjang sehingga hasil yang diperoleh akan lebih dapat digeneralisasi dan akan lebih menggambarkan kondisi sesungguhnya selama jangka panjang. Selain itu dapat menambah variable lain yang diduga mempengaruhi ketepatan waktu pelaporan 
keuangan seperti kualitas sistem pengendalian intern, opini audit, dan peranan audit internal perusahaan. 


\section{DAFTAR PUSTAKA}

Ang, Robert. 1997. The Intelligent to Indonesian Capital Market. Edisi 1. Mediasoft. Indonesia.

Anissa, Nur. 2004. “Ketepatan Waktu Penyampaian Laporan Keuangan : Kajian Atas Kinerja Manajemen, Kualitas Auditor dan Opini Audit”. Balance No 2 (September), 42-53.

Baridwan, Zaki. 1997. Intermediate Accounting. Edisi Tujuh. Cetakan Pertama.Yogyakarta: BPFE.

Ghozali, Imam. 2007. Aplikasi Analisis Multivariate dengan Program SPSS. Badan Penerbit Universitas Diponegoro. Semarang.

Indriantoro, Nur dan Bambang Supomo. 1998. “Metodologi Penelitian Bisnis Untuk Akuntansi dan Manajemen". Edisi Pertama. Cetakan Pertama. BPFE. Yogyakarta.

Ikatan Akuntan Indonesia. 2007. Standar Akuntansi Keuangan. Penerbit Salemba Empat. Jakarta.

Keputusan Ketua Bapepam No 80/PM/1996 . No : Kep-36/PM/2003

Kieso, Donald. E.,et al. 2002. Akuntansi Intermediate Edisi kesepuluh Jilid 1. Diterjemahkan oleh Emil Salim. Penerbit Erlangga. Jakarta.

Na'im, Ainun. 1999. "Nilai Informasi Ketepatan Waktu Penyampaian Laporan Keuangan : Analisis Empirik Regulasi Informasi di Indonesia”. Jurnal Ekonomi dan Bisnis Indonesia Vol.14, No.2, 85-100.

Natawidnyana, 2008. "Sejarah Big Four Auditors." Forum: Just another WordPress.com weblog. http://www.wordpress.com, diakses 24 Agustus 2010.

Oktorina, Mega dan Suharli, Michell. 2005. "Studi Empiris Terhadap Ketepatan Waktu Pelaporan Keuangan". Jurnal Ekonomi dan Bisnis. Universitas Katolik Indonesia Atma Jaya. Jakarta.

Respati, Novita, Weningtyas. 2004. "Faktor-Faktor Yang Mempengaruhi Terhadap Ketepatan Waktu Pelaporan Keuangan : Studi Empiris di Bursa Efek Jakarta", Jurnal Maksi, Vol.4, pp.67-81.

Surat Edaran Ketua Bapepam No. SE-02/PM/2002 
www.bapepam.go.id

www.idx.co.id 
